\title{
Ragged Schools in Sydney
}

\author{
EUREKA HENRICH
}

$\mathrm{D}$

uring the late nineteenth and early twentieth centuries Ragged

Schools were a feature of many of Sydney's overcrowded innercity suburbs. The first was opened in Sussex Street in 1860 and by 1910 the privately-run philanthropic Schools had spread to Millers Point, Glebe, Surry Hills and Woolloomooloo. Improved social welfare and public education provisions in the mid-1920s made the Ragged Schools obsolete. It is estimated that in their sixty years of operation around 18,000 children attended Sydney's Ragged Schools. ${ }^{1}$

\section{THE ORGANISATION AND THEIR AIMS}

Led by Newtown merchant Edward Joy, the original committee of the Sydney Ragged Schools consisted mostly of Protestant laymen and clergy. They were affluent charity-minded members of society who all shared a concern for the moral state of the colony, particularly the 
alarming number of children visible on city streets at all hours of the day and night. The solution, as they saw it, was to establish an industrial school that would provide these children with a basic education, skills to become 'useful' men and women and, most importantly, to 'save' them from an otherwise inevitable future of depravity and crime through knowledge of the Bible. Edward Joy described the three central aims of the organisation in 1862: 'to make the children love God and their parents; to get them on in reading and writing, and to put them in the way of earning their own livelihood'. ${ }^{2}$

What set the Ragged Schools apart from other middle-class charity groups was that the focus of educational and moral reformation was not only the children but also their parents. Unlike colonial systems of child institutionalisation in state-run orphanages, or asylums run by charities such as the Society for the Relief of Destitute Children, the philosophy of the Ragged School movement both in Australia and its precursors in England and Scotland was that children of the 'perishing classes' could be 'saved' without physically removing them from their homes. The practice of visiting the homes of the poor by teachers of the Ragged Schools was a key factor in the implementation of these aims. In this way the Schools' methods were ahead of their times, foreshadowing later social work practices. Yet their attitudes to poverty and its causes were lodged firmly in the nineteenth century.

\section{AN IMPORT FROM THE MOTHER COUNTRY?}

The first ragged schools emerged in Britain in the late eighteenth century, although it was not until 1844 that nineteen schools in London joined together to form the Ragged School Union. The Ragged Schools aimed to provide a free education for the poorest of the poor, many of whom were not accepted into other institutions due to their rowdy behaviour, dirty or untidy appearance and their parents' inability to pay even the smallest fees. These were the reasons given by those who ran the Schools, but other reasons, such as children working to supplement their family's income, were also important, and were not as easily incorporated into Victorian middle-class ideas about the causes of poverty. Most often it was the idleness and drunkenness of parents that were cited as reasons for their children's visible poverty. The free education offered by the Ragged Schools came with strong moral and religious overtones aimed at correcting this parental behaviour.

The London Ragged School Union, and later developments including the Liverpool Ragged School Union (1847) and the Manchester and Salford Ragged School Union (1858), provided a model for the 
establishment of Ragged Schools in Australia. Australia's colonial port towns were shifting immigrant communities, and many people who became involved in Ragged Schools there had experience in similar organisations back 'home'. In 1862 the Committee of the Sydney Ragged Schools observed in their Second Annual Report 'indications that the inhabitants of this colony are anxiously endeavoring to imitate the excellent example which is set before them by the noble and the good in Great Britain.' ${ }^{3}$ Eight years earlier, in 1854, the Hobart Town Ragged School Association was formed in Tasmania with the intention of running its schools according to 'the principles of the British Ragged Schools'. ${ }^{4}$ Four schools were eventually established in the 'slum' areas of Hobart. Melbourne followed suit in 1859 by opening a Ragged School in the suburb of Collingwood, the first of thirteen schools run by the Hornbrook Ragged School Association. ${ }^{5}$ Although the Victorian and Tasmanian Ragged Schools pre-dated those in Sydney, they declined sooner, and operations had ceased by the early 1910s. ${ }^{6}$ By contrast, the Sydney Ragged Schools continued into the mid 1920s.

\section{WHY WERE THERE RAGGED SCHOOLS IN SYDNEY?}

The Ragged School movement in Great Britain was an important influence on the establishment of Ragged Schools in Sydney. Other social and demographic factors were home-grown, and occurred in the decade before the Schools opened.

\section{Suburban sprawl and urban poverty}

Sydney of the 1850s was a colony only recently separated from its convict origins, a vast and expanding metropolis struggling with the competing values of new-world modernity and old-world traditions. The emerging affluent middle class was keen to distinguish itself from the mass of new immigrants, workers and, worst of all, 'slum-dwellers' who they saw as bringing disrepute to the colony. They began to move to new suburbs such as Randwick to live healthier, non-urban lives while workers remained in the city areas, close to the industries which employed them. Sydney was not yet industrialised and had no mass public transport system. Working men and women either worked from home or walked. By moving away from the city, affluent families removed themselves from industries and people that they saw as beneath them. ${ }^{7}$

There was an underside to these demographic shifts. As industry encroached on city living spaces, rents began to rise, resulting in overcrowding and poor sanitary conditions. ${ }^{8}$ Sydney was growing at a 
pace faster than the government could plan for, and the poorer itinerant workers and their families residing in the city areas had no choice but to 'make do' under difficult circumstances. Many families were put under greater financial stress when male family members left to try their luck on the gold fields of New South Wales and Victoria. Women's and children's labour, networks of friends and family, and the services of charities became essential to the survival of these and other lower working class families.

Moral and educational reform: a project of the respectable classes Moral and educational reform were areas of grave concern for the respectable classes of Sydney in the mid-nineteenth century. 'Street arabs', as children on the streets were called, symbolised to them all that was wrong with certain areas of Sydney. These children appeared rough and disorderly, and did not regularly attend school or church. The Final Report from the School Commissioners in 1855 observed:

In Sydney, not more than half the children of the lower classes attend school. At particular times the quays and wharfs, as well as most open public places, may be seen crowded with idle children, who there learn to use bad language, to steal, and to practice every indecency. ${ }^{9}$

The remainder of the report detailed the existing problems in the state's public schools, including punctuality, discipline and the timely payment of schools fees. It is clear that the school inspectors already had their hands full with the children attending the public schools, and that the 'children of profligate parents' - parents who could not afford the school fees - were not a high priority. ${ }^{10}$ This created an opportunity for philanthropists and clergy to provide the education (and reformation) that the public system failed to make universally available.

\section{A 'darkening mass of physical and moral disease'}

By 1859 the momentum towards opening Ragged Schools in Sydney was strong. In that year in the NSW Legislative Assembly Henry Parkes, who would later become a supporter of the Ragged Schools, moved that a Select Committee be appointed to report upon the 'social condition of the working classes of this metropolis'. ${ }^{11}$ This was the first official attempt to gather information regarding the causes of poverty, rather than just the effects. But despite recognising the real and tangible problems of diminishing wages, lack of employment and the effect on families of the gold rushes ('the consequence is a large amount of 
destitution and misery'), the report also assumed the poor were morally corrupt, irresponsible and unclean. Medical witnesses testified that 'the want of proper accommodation has a direct effect on the moral sense of the occupants', obscuring the fact that physical health problems were caused by a lack of nutrition, access to doctors and the absence of sanitation or a clean water supply. Other witnesses merely provided a commentary on their expeditions into poor areas:

It is lamentable to discover this darkening mass of physical and moral disease... inside and out, everything is an object of disgust, and wears a look of loathsomeness that would terrify men away. ${ }^{12}$

\section{Finding new solutions}

During the 1850s a number of charitable organisations aimed at saving the 'dangerous classes', such as the City Mission and the Asylum for Destitute Children, began to provide aid and care to fill the gap left by a lack of government assistance. Their work was informed by the Christian duty to help those who were less fortunate as well as a utilitarian impulse to prevent future crime. Older institutions such as the orphan schools and the Benevolent Asylum were still operating, although their effectiveness and scope were frequently criticised and new solutions were sought. ${ }^{13}$ Some churches and individuals began opening schools for poor children. Mrs Reid, the wife of Reverend John Reid, began teaching classes in a schoolroom adjoining the Scots Church in February 1860. As she had run a similar school in Johnstone in Edinburgh, Scotland, she called it by the same name, a 'ragged school'. ${ }^{14}$ However, this school was not affiliated with the Sydney Ragged Schools, which began in the same month.

\section{THE COMMITTEE OF THE SydNeY RAgGed SCHOOLS}

The Sydney Ragged School movement was entrepreneurial from the start. The men who came together in February 1860 to form the first committee were a mix of religious leaders and affluent charity-minded members of society, who had already raised $£ 300$ to hire a hall in Sussex Street 'a little south of the Pyrmont Bridge', fit it out as a school room and pay the salary of the school master. ${ }^{15}$ The committee, led by Edward Joy, also included Anglican clergy such as Bishop Barker, the Dean of Sydney, the Reverends John West and S.C. Kent and evangelical laymen such as A. Gordon, a prominent Anglican, S. Hebblewaite, J. Caldwell and J.R. Houlding. ${ }^{16}$ The committee changed and shifted over its sixty years of operation and later prominent members included NSW 
Governor Sir John Young, newspaper proprietors Sir John Fairfax and his son, Sir James Fairfax, and the ships' providore John Thomas Playfair. The committee remained non-denominational and mixed between respectable citizens and clergy. Although only men sat on the committee, the members' wives and daughters played a large part in the running of the organisation. They collected donations of clothing, organised special functions, visited the schools and gave special treats for the children such as picnics and excursions.

The mission of the committee was to make some effort to benefit the neglected young children of Sydney, and their adoption of the name 'Ragged Schools' served this aim in two ways. It associated the organisation with the well-known Ragged Schools in Great Britain, whose deeds were regularly reported in the Sydney press, and thus helped to elicit donations or 'subscriptions' from well-to-do Sydney residents for similar schools in the colony. ${ }^{17}$ It also prevented the attendance of those who could afford to go elsewhere. The name 'ragged school' carried a stigma of dirt, poverty and uncleanliness, and although concerns were raised that this stigma might prevent the social rise of former ragged scholars, the name was the key to the organisation's identity and thus its success as a recognisable and admirable cause in the eyes of those who supported it. ${ }^{18}$

\section{LOCATIONS OF THE RAGged SCHOOLS IN SYDNEY}

It is no coincidence that the committee chose Sussex Street as the first site for a ragged school. It was right in the centre of the most densely populated part of the city - a perfect place to begin to 'elevate the degraded and reform the vicious'. ${ }^{19}$ The attention of the committee was then drawn to the 'neglected districts' of the Rocks and Woolloomooloo Bay, where they hoped to open branch schools as soon as possible. ${ }^{20}$ Funds were raised by special subscription and the Globe Street School in the Rocks was opened as a result in 1862, but financial difficulties meant that a Woolloomooloo School was not established until many years later. ${ }^{21}$ Meanwhile, in 1863 the Sydney Ragged Schools took over responsibility for a privately run school for the poor in the Glebe, near Blackwattle Bay. This became the third Ragged School, and these three schools remained in operation until the movement disbanded in the 1920s. During this time they all changed location. Some shifted three or four times and were replaced by schools in other areas.

When its lease expired in 1872, the original Sussex Street School moved to a new purpose-built school in Kent Street. It moved again to Brisbane Street in 1889. That School closed in 1908, and was replaced by 
the Jubilee School in Surry Hills in 1910. The original Globe Street School moved to Harrington Street in 1875. It closed in 1910 and was replaced by a new school in Miller's Point in 1912. The Glebe School moved from its original premises on the corner of Bay and Glebe Streets to a new building in Water Street in 1896, where it remained until it closed in 1927. ${ }^{22}$ New schools in Waterloo (1886) and Woolloomooloo (1895), as well as the new locales of the original three schools, trace the expansion of Sydney, patterns of slum clearance and the resulting movement of the urban working poor away from the central business district.

\section{TEACHERS}

A child's attendance at one of Sydney's Ragged Schools usually began with a home visit from a Ragged School teacher. Teachers canvassed the new areas designated for schools, seeking out children to enroll and explaining to parents the object of their instruction. They also kept journals, excerpts of which were published in the organisation's Annual Reports. In 1904 the nine teachers employed by the committee were described simply as 'devoted Christian women. ${ }^{23}$ We learn little of their personal lives from the Annual Reports, but one teacher, Miss Danne, is mentioned by name in the early years of the organisation.

Miss Danne began teaching at the Sussex Street School along with her father, Mr Danne, a few months after it opened. She was a busy woman, running mothers' meetings, a clothing club, Sunday evening meetings, as well as visiting the homes of students and prospective students, and teaching classes during the afternoons for boys and girls. It is likely that Mr Danne taught the evening classes which were for boys only, who came after they had finished their work for the day. Scholars in the industrial department were paid a small sum for the work they undertook, such as making paper bags. Part of the amount was deposited on their behalf into the penny savings bank. All children, who in 1861 ranged in age from four to eighteen years, were taught reading, writing, arithmetic and given religious instruction. The girls were also taught to make and mend their own dresses. ${ }^{24}$

Miss Danne had a strong belief in the power of the Bible to teach habits of self-respect and decency. Teaching in the Ragged Schools was thus a way to apply her Methodist beliefs, and be remunerated for her efforts. Unlike in Great Britain, where male teachers were often thought to be more suited to the work, in Sydney the Ragged Schools committee decided that female teachers could morally nurture scholars due to their maternal instincts. This placed them in opposition to the scholar's mothers, who were seen as lacking that maternal instinct and inherent 
goodness. For Miss Danne and the other single young women who worked in the Ragged Schools, the job allowed them to earn a living while maintaining their feminine virtues and respectability. They were not required to have any teaching qualifications, as the role was seen as primarily missionary rather than educational.

\section{VISITING SCHOLARS' HOMES - OR STEPPING INTO THE SLUM?}

Most of the teachers' journal excerpts published in the Sydney Ragged School's Annual Reports would lead us to believe that children who attended the Schools were at best uncared for, and at worst, abused or neglected. Teachers and committee members saw their home environments, both in the physical and the moral sense, as a source of danger, describing them not as family homes, but as dens or rookeries. The first Annual Report of 1861 describes the home of three boys as 'a miserable hovel in a very low quarter of the city'. As a result these boys were 'filthy in their habits and language, restless, careless and ungovernable'.$^{25}$ Twenty years on, in 1882, a teacher remarked on the 'offensive' atmosphere she encountered as she entered the home of one scholar. ${ }^{26}$ Later still, in 1916, one teacher wrote:

Visited a home to see the new baby; a home I said, I hardly know how to describe it. The place had very little in it. Amongst a lot of rags on the miserable bed lay the mother and infant. Other four children running in and out dirty and ragged. The mother said the night the baby was born the father was so ill that they thought he was going to die. He is a very delicate man. They are thankful for food prepared in the School, and, as they live close, we saw that the mother had some nourishment also.

While it is true that many of these children lived in poverty, and that the help of the Ragged School teachers was often gratefully received, the teachers' descriptions of their homes have more in common with the slum fiction of Victorian England than they do with the experiences of Sydney's urban poor. As historian Grace Karskens observed when surveying these sources for her work on the Rocks, the committee needed 'ghastly (and frightening) stories of human misery to raise money for their schools. Emphasising tales of decency, comfort and selfdiscipline would not have kept subscribers on the roll. ${ }^{27}$ 


\section{BEYOND THE SLUM STEREOTYPE}

Positive stories were relayed in the teachers' journals, but they were often stories of reformation, contrasting the child or parent before their encounter with the Ragged Schools, and after. In 1861 Miss Danne wrote that many of her students, 'from being liars, crafty, deceitful and using immoral words, have become modest, obedient and loving.' Part of the Ragged School's work in later years was to encourage parents to take the 'temperance pledge', and agree to stop drinking. Stories of children using their new-found piousness to persuade their parents to come to the schools to take the pledge appeared in a number of reports. But these stories, and others, such as mothers carefully sewing new bonnets for their children, or coming to the schools to thank the teachers for giving their children the skills to read and write, also suggest warmer relationships of accommodation and reciprocity.

In later years, when former-Ragged School boys were serving in the AIF during the First World War, they wrote letters back to their old school teachers, again hinting at the affection and goodwill that was part of their education. Reading between the lines of the Annual Reports encourages us to see the real men and women, boys and girls, who attended and worked at the schools, rather than the common stereotypes wrought through the constraints of respectability.

\section{AN OfFER OF HELP DECLINED}

The Ragged Schools prided themselves on providing an education to those who could not attend the public schools. But the failure of the public schools to cater for these children was somewhat of an embarrassment for the Government. In 1878 the Council of Education made an offer to help the 'neglected classes' by paying the teachers' salaries and other costs associated with the running of Sydney's Ragged Schools. This represented a turning point for the organisation. In spite of financial hardship and limited resources, they chose not to accept the Council of Education's 'overtures'. Correspondence between the then secretary of the schools, J.S. Harrison, and the secretary to the Council of Education, W. Wilkins, reveals the reasons for the refusal, being that 'biblical teachings administered throughout the day' might be interfered with, that the present teachers may not suit the Council's requirements and may be 'thrown out of employment' and, finally, that Council administration would 'in all probability cause the cessation of subscriptions' ${ }^{28}$ These objections were made throughout the history of the Ragged Schools in Sydney. ${ }^{29}$ 
The relationship between the Government and these special schools remained a philanthropic one. The Ragged Schools were happy to accept material gifts, such as a free train ride to Homebush for their Annual Treat in 1862, or small, infrequent monetary grants, but refrained from entering into any partnership on an administrative level, which would interfere with its authority. ${ }^{30}$ In 1916 the Annual Report notes a donation from the Department of Public Instruction of a 'large quantity of books', suggesting that the syllabus taught was quite similar to that of the public schools. ${ }^{31}$ Clearly any objection to government aid was not just because of opposing ideas about what should be taught, but how. As one influential committee member, Justice Edward Wise, said in 1862:

it would be far better for these schools to be supported entirely by voluntary contributions, because then their exertions could be made without the trammels which must be imposed whenever such institutions were brought under the direction of the Government. ${ }^{32}$

By maintaining control over enrolments, teachers, school sites, curriculum and activities the Sydney Ragged Schools were able to continue their unique approach to educating not only children but also families of a distinct underclass. Despite some debate within the committee as to the ethics of accepting varying degrees of government aid, overall they vigorously defended their autonomy throughout their sixty years of operation. ${ }^{33}$ However, this separatism entrenched the marginilisation of the Ragged Schools within the education sector and ultimately contributed to their demise in the mid-1920s.

\section{DWINDLING ATTENDANCE}

Poor attendance was one problem that the Ragged Schools shared with Government schools. Teachers frequently complained of the trouble of getting children to school with any regularity. ${ }^{34}$ Many times the Ragged School committee attempted to explain the lack of attendance, calling on a few recurring themes. Most popular in the reports was the bad-parent theme, as demonstrated by the following remark from a teacher at the Waterloo Ragged School in 1900: 'if parents would only show a deeper interest in their child's welfare we would have many more in our schools ${ }^{\prime} .{ }^{35}$ Similarly, there is an anecdote from the same school's teacher in 1898 about a child who was 'kept home against her will to sell flowers in the street'. ${ }^{36}$ Lack of attendance due to inadequate parenting was often linked to the physical appearance of the children, for example 'during the winter months many children do not have sufficient clothing or are 
kept home while their clothes are washed' ${ }^{37}$ A striking example of this kind of rhetoric occurred in the 1879 Annual Report: 'One poor girl said to me today "I want to go to school, but mother won't wash my clothes". The child was so filthy that I could not ask her to come with $m e^{\prime} \cdot{ }^{38}$ One must also wonder what befell the children who were turned away from the schools that purportedly offered a welcome to every 'neglected child' ${ }^{39}$

The 1880 Annual Report shows that the Ragged Schools were enthusiastically expecting an increase in attendance due to the new compulsory clause in the Education Act, which required all children to attend school no less than 140 days of the year. ${ }^{40}$ However, just a year later, in 1881, their hopes had been partially dashed:

The question of compulsory attendance of such children is a most difficult one to deal with, the girls often being kept at home to run messages or to mind smaller children while mothers are employed out working; while many of the boys are engaged a portion of the day in selling daily papers and their small earnings being required to supplement those of their parents. ${ }^{41}$

For many working-class families, the earnings of their children were of greater immediate value than their attendance at school. As Craig Campell and Geoffrey Sherington have argued, it took many years for a 'culture of schooling' to develop in these communities. ${ }^{42}$ Rather than probing the reasons why children were kept home to work, the committee continued to blame the children's parents for their absences. James Murray's popular history of larrikinism remarks: 'it was the parents who would always be blamed for their child's delinquency. There were some prosecutions for failure to send children to school, but the actions were generally infrequent and so ineffective' ${ }^{43}$

\section{'MUCH SICKNESS'}

In addition to their poor clothes, dirty appearance and daily chores or work, the Sydney Ragged School committee also noted that hunger and disease often affected the attendance of the scholars. Epidemics such as measles, whooping cough, influenza and diphtheria had the most devastating effect on poor Sydneysiders. ${ }^{44}$ In 1882 the Kent Street School was forced to close for three weeks after an outbreak of smallpox in the area, one little girl 'being laid aside with the disease' ${ }^{45}$ During the 1890 s depression years constant reference is given to the health of the scholars. 'Much sickness' prevailed in 1903 when 'all children were affected' ${ }^{46}$ 
During the winter months, when all children suffered colds, 'a mixture was given which relieved them very much'. In 1907 teachers at the Woolloomooloo School noted that it had been a 'trying winter for poor people, measles and whooping cough being in almost every home' ${ }^{47}$ Children were often absent from school because of their own sickness, or because one of their family was ill.

\section{LATER YEARS}

The introduction of daily meals in the late 1890s can be seen as a response to declining attendance and an attempt to improve the health of the children. The promise of food also changed the function and image of the Ragged Schools. It was a clever drawcard for new recruits and most probably played a part in the continuation of the Schools through the depression and into the twentieth century. ${ }^{48}$ This new feeding function separated them further from mainstream public schools, bringing them more in line with out-door relief organisations such as the Benevolent Asylum and the City Mission (which were already assisting some 'deserving' Ragged School families). ${ }^{49}$ These charities ran strictly on the basis of helping those deemed sufficiently humble and grateful, suggesting that the Sydney Ragged Schools were keen to portray themselves in the same light.

\section{'NO LONGER SO MUCH OF THE OLD DISTINCTION'}

While compulsory education and the provision of more public schools did not immediately eradicate the need for Ragged Schools, it did slowly begin to erode the numbers of children attending class. By 1912 the Committee had constructed a version of events to present to their subscribers in the Annual Report - one that accounted for the drop in enrolments and brought to the readers' attention the reasons why the work should continue. The report conceded that free education in public schools made a 'slight difference', and that 'resumptions and improvements in the more congested city areas' had forced many families to move out of the areas targeted by the schools, making smaller enrolments 'unavoidable'. ${ }^{50}$ While the number of children targeted may have declined, the teachers and committee members of the Sydney Ragged Schools still believed in their special mission: to seek out and save the poor. The Annual Report of 1912 observed 'that there is no longer so much of the old distinction between the ordinary children of the Public Schools, and the poor children among whom our teachers work'. Yet it also insisted that 'while this is so, there is still in the districts where 
the Schools are situated a considerable residuum where the work and influence of the Schools are much needed' ${ }^{51}$

By this stage two of the original schools had closed and were reopened in the new areas of Millers Point and Surry Hills. Photographs were published for the first time in the Annual Reports of 1912 and 1913, which reveal neatly dressed children with carefully braided hair, cheerfully decorated school rooms and smiling children in playgrounds. If it were not for the captions, these photographs would be indistinguishable from similar ones taken at public schools at the same time. Although some children lacked shoes, this was not unusual among the poorer families of many areas in Sydney. Attendance at these 'new' Ragged Schools may have been aided by overcrowding at the public schools, rather than by a surplus of 'dangerous classes'. Indeed, that kind of rhetoric was becoming rarer. Attitudes towards the causes of poverty had shifted markedly from the mid-nineteenth century, and charities were no longer the only option for working-class families struggling to stay healthy and employed. Many factors came together to change the provision of health and welfare, away from the moralistic charity model, and towards a universal rights-based approach where both the state and federal governments assumed greater responsibility for the wellbeing of their citizens. ${ }^{52}$

Education reform continued as well. In 1916 the compulsory clauses of the 1880 Act were amended, requiring all children to attend school every day, not just for 140 days of the year. Geoffrey Sherington has argued that these changes, more than any before, were 'significant for transforming the attitudes of working-class families to the labour and schooling of their children. ${ }^{53}$ With more working-class children attending school, and a greater expectation that all children deserved equal educational opportunities regardless of their family's economic or social circumstances, the attitudes and methods of Sydney's Ragged Schools were rendered unjustifiable and old fashioned. By the end of the 1920s, they had faded into the history of old Sydney, and have remained largely hidden ever since.

\section{RAGGED SCHOOLS IN MEMORY AND FICTION}

While many thousands of Australians experienced their education or part of it at a Ragged School, these experiences have not formed a part of any communal remembering. Some ex-scholars never spoke of their ragged schooling, not even to their children. ${ }^{54}$ These silences suggest a stigma felt by ex-scholars. The Ragged Schools by their very name were somewhere to be avoided if at all possible. The term 'ragged school' was 
used as a deterrent to those who could afford to avoid its associations of dirt, filth, poverty and disrepute. Accordingly, there are no ex-student organisations, or proud school histories, and records are scarce. Despite the chances that a Ragged School education may have given them, or the practical help they may have received, it remains an experience that some would rather forget.

This forgetting is reflected on the streets of Sydney today. Even in the Rocks, which has been shaped into an old-world place, tourists exploring the area would find no trace of the Ragged Schools that once operated in Globe Street, in Harrington Street and later, in Millers Point. The only building used as a Ragged School that still stands is in Waterloo and was originally a Congregational Chapel. It has been recognised by the NSW Office of Environment and Heritage as a place of 'historical and social significance as it provided moral support and education for the underprivileged local residents, particularly the children of the poor.' Much more remains to be said about why these children were schooled outside the public school system and maintained as a distinct underclass long after ideas of the 'dangerous' or 'perishing classes' were current. In the UK, where there were many more ragged schools, there is a greater public memory of their presence and their work and more records of their existence. A Ragged School Museum in London's East End operates tours for local school groups where students can imagine what it would be like to be a ragged scholar. This history is relevant to debates about education today, both in Australia and abroad.

What most Australian schoolchildren know of the Ragged Schools comes from Ruth Park's vivid novel, Playing Beatie Bow. In the novel, Sydney teenager Abigail Kirk finds herself transported back in time to a place that is 'foreign, yet strangely familiar' ${ }^{55}$ In this place - the Rocks of late-nineteenth century Sydney - the fierce child Beatie resents having to learn to patch and to curtsey for the lady visitors at the Harrington Street Ragged School, while the boys get to learn Latin and algebra. According to Park's story, children like Beatie were chided for having no shoes and caned for the slightest infraction.

This story is of course fiction. The character of Beatie, as the child of a shopkeeper, is unlikely to have endured the shame of being a ragged scholar. The boys at Harrington Street Ragged School would not have learnt Latin: that type of education was not relevant to their prospects. And the Ragged School teachers avoided physical punishment, believing that many of their pupils were subject to beatings at home and would not respond well to similar treatment at school, although the extent to which these assumptions were true remains unsubstantiated. Park's description of the Rocks also draws on many of the same slum 
stereotypes that the committee of the Ragged Schools used to gain support for their Christian endeavours. These constructions need to be questioned by historians, and can be remedied by projects like family histories, which give personality and meaning to the otherwise anonymous or fictional 'slum-dwellers'. In this way the history of the Ragged Schools may some day be written back onto the streets of Sydney.

Eureka Henrich is Honorary Research Associate, Menzies Centre for Australian Studies.

\section{ENDNOTES}

${ }^{1}$ Chris Murray, 'The Ragged School Movement in New South Wales 1860-1924', Masters thesis, Macquarie University, 1979, p2.

${ }^{2}$ The Sydney Mail, April 12, 1862.

${ }^{3}$ Sydney Ragged Schools Annual Report, No.2, 1862, Mitchell Library.

${ }^{4}$ John Ramsland, 'The Development Of The Ragged School Movement In Nineteenth-Century Hobart', Journal of the Royal Australian Historical Society, vol 73, no 2, October 1987, p127.

${ }^{5}$ John Ramsland, 'The Ragged School Systems In The Australian Colonies', Victorian Historical Journal, vol 60, nos. 2-4, September 1989, p48.

${ }^{6}$ John Ramsland, 'The Ragged School Systems In The Australian Colonies', Victorian Historical Journal, vol 60, nos. 2-4, September 1989, p53.

${ }^{7}$ For more on the suburban shift and the rise of respectable and middle-class culture see Richard Waterhouse, Private Pleasures, Public Leisure, Longman, South Melbourne, 1995, especially pp101-103.

${ }^{8}$ Stephen Garton, Out of Luck: Poor Australians and Social Welfare 1788-1988, Allen \& Unwin, Sydney, 1990, p39.

${ }^{9}$ New South Wales Legislative Council on Education, The Final report from School Commissioners to Inquire into the State of Education in the Colony, Government Printer, Sydney, 1855, p262.

${ }^{10}$ New South Wales Legislative Council on Education, The Final report from School Commissioners to Inquire into the State of Education in the Colony, Government Printer, Sydney, 1855, p262.

${ }^{11}$ New South Wales Legislative Assembly, Report from the Select Committee on the Condition of the Working Classes of the Metropolis Together with the Minutes of Evidence and Appendix, Sydney, Government Printer, 1860, vol 4, p3.

${ }^{12}$ New South Wales Legislative Assembly, Report from the Select Committee on the Condition of the Working Classes of the Metropolis Together with the Minutes of Evidence and Appendix, Government Printer, Sydney, 1860, vol 4, p10.

${ }^{13}$ New South Wales Legislative Council, Progress Report from the Select Committee on Destitute Children with Minutes of Evidence, Sydney: Government Printer, 1854. This report includes discussion of alternative methods to orphan schools, including boarding out, reformatories and industrial schools.

${ }^{14}$ The Empire, 27 July 1860, p4.

${ }^{15}$ The Empire, 27 July 1860, p4.

${ }^{16}$ John Ramsland, Children of the Back Lanes: Destitute and Neglected Children in Colonial New South Wales, New South Wales University Press, Kensington, 1986, p91.

${ }^{17}$ See, for instance, The Empire, 27 July 1860, p4, which provides proud history of the Ragged Schools in London and Edinburgh as an introduction to similar schools opening in Sydney. 
${ }^{18}$ Sydney Ragged Schools, Annual Report, no 1, 1861, Mitchell Library. The committee noted that calling it the 'free school' attracted the wrong type of children. Concerns about the stigma of 'ragged schools' were raised again in 1910. See The Presbyterian Messenger, November 25, 1910, p759.

${ }^{19}$ Sydney Ragged Schools, Annual Report, no 1, 1861, Mitchell Library.

${ }^{20}$ Sydney Ragged Schools, Annual Report, no 2, 1862, Mitchell Library.

${ }^{21}$ In their assessment of the Woolloomooloo area, teachers began home visits, collecting a roll of 32 unschooled children. Sydney Ragged Schools Annual Report, no 35, 1895, Mitchell Library.

${ }^{22}$ Margaret Penson, The Glebe ragged school, Leichhardt Municipal Library, Leichhardt, NSW, 2001, p1.

${ }^{23}$ Sydney Ragged Schools, Annual Report, no 44, 1904, Mitchell Library.

${ }^{24}$ Sydney Morning Herald, 2 February 1861, p5.

${ }^{25}$ Sydney Ragged Schools, Annual Report, no 1, 1861, Mitchell Library.

${ }^{26}$ Sydney Ragged Schools, Annual Report, no 22, 1882, Mitchell Library.

${ }^{27}$ Grace Karskens, Inside the Rocks: The Archaeology of a Neighbourhood, Hale \& Iremonger, Alexandria, NSW, 1999, p188.

${ }^{28}$ John McDonald, District Visitor for the Council of Education, to W. Wilkins, Secretary to the Council of Education, 22 May 1878. Handwritten manuscript held in file 20/13029 'Ragged Schools', State Records NSW. The Council of Education became the Department of Public Instruction in 1880.

${ }^{29}$ The only financial aid the Sydney Ragged Schools ever received from the Government were a few stationary grants, of only twenty pounds each, and a gift of fifty pounds to give the children a special treat in anticipation of Coronation festivities. J.S.Harrison, Hon. Secretary of the Sydney Ragged Schools, to the Minister for Public Instruction, 26 July 1882, handwritten manuscript held in file 20/13029 'Ragged Schools', State Records NSW. The coronation festivities mentioned in Sydney Ragged Schools Annual Report, no 42, 1902.

${ }^{30}$ Sydney Ragged Schools, Annual Report, no 2, 1862, Mitchell Library.

${ }^{31}$ The similarity of secular syllabi is noted in Murray, 'The Ragged School Movement in NSW', pp60-1.

32 Speech by Justice Wise at the second Annual Meeting of the Sussex Street Ragged and Industrial School, quoted in Chris Murray, 'The Ragged School Movement in New South Wales 1860-1924', Masters thesis, Macquarie University, 1979, p65.

${ }^{33}$ Chris Murray found that there was some support for state aid among Anglicans in the early years, although only small favours were accepted due to concern that religious element would be tampered with. Chris Murray, 'The Ragged School Movement in New South Wales 1860-1924', Masters thesis, Macquarie University, 1979, pp65-66.

${ }^{34}$ New South Wales Legislative Council on Education, The Final report from School Commissioners to Inquire into the State of Education in the Colony, Government Printer, Sydney, 1855, p22.

${ }^{35}$ Sydney Ragged Schools, Annual Report, no 40, 1900, Mitchell Library.

${ }^{36}$ Sydney Ragged Schools, Annual Report, no 38,1898, Mitchell Library.

${ }_{37}$ Sydney Ragged Schools, Annual Report, no 36,1896, Mitchell Library.

${ }^{38}$ Sydney Ragged Schools, Annual Report, no 19, 1879, Mitchell Library.

${ }^{39}$ Sydney Ragged Schools, Annual Report, no 52, 1912, Mitchell Library.

${ }^{40}$ Sydney Ragged Schools, Annual Report, no 20, 1880, Mitchell Library.

${ }^{41}$ Sydney Ragged Schools, Annual Report, no 21, 1881, Mitchell Library.

${ }^{42}$ Craig Campbell and Geoffrey Sherington, 'Education', Dictionary of Sydney, 2008, http:/ / www.dictionaryofsydney.org/entry/entry/education, viewed 26 September 2012.

${ }^{43}$ James Murray, Larrikinism, $19^{\text {th }}$ Century Outrage, Landsdowne Press, Melbourne, 1973, p 109.

${ }^{44}$ At the turn of the century, 'not all groups participated equally in the improving health and living conditions... the highest mortality being associated with a central group of suburbs, where blue-collar or unskilled workers resided or where 
industry had located', Peter Curson and David McCracken, Plague in Sydney: The Anatomy of an Epidemic, Kensington: New South Wales University Press, 1989, pp86-87.

${ }^{45}$ Sydney Ragged Schools, Annual Report, no 22, 1882, Mitchell Library.

${ }^{46}$ Sydney Ragged Schools, Annual Report, no 43, 1903, Mitchell Library.

${ }^{47}$ Sydney Ragged Schools, Annual Report, no 47, 1907, Mitchell Library .

${ }^{48}$ Food aid first began unofficially at the Harrington Street School in 1898. Regular meals were an initiative started anonymously in 1905 by a 'deeply interested friend' who offered to 'bear the entire cost at one of the schools'. In the following year the beneficent source was revealed as Sir John Fairfax, a long-time supporter and influential committee member of the Schools. In the same year the Lord Mayor of Sydney replaced his annual treat for the children with a donation of $£ 20$ for relief during the winter. Sydney Ragged Schools, Annual Report, no 45, 1905, Mitchell Library.

${ }^{49}$ Sydney Ragged Schools, Annual Report, No.36, 1896, Mitchell Library.

${ }^{50}$ Sydney Ragged Schools, Annual Report, No.52, 1912, Mitchell Library.

${ }^{51}$ Sydney Ragged Schools, Annual Report, No.52, 1912, Mitchell Library.

${ }^{52}$ Stephen Garton, 'Health and welfare', Dictionary of Sydney, 2008, http:/ / www.dictionaryofsydney.org/entry/entry/health_and_welfare, viewed 27 September 2012.

${ }^{53}$ Craig Campbell and Geoffrey Sherington, 'Education', Dictionary of Sydney, 2008, http:/ / www.dictionaryofsydney.org/entry/entry/education, viewed 26 September 2012

${ }^{54}$ Eureka Henrich, 'Wild and whimsical: the history of Sydney's Ragged Schools 1860-1924', Honours thesis, University of New South Wales, 2006, especially Chapter 3, 'Children, parents and family life'.

${ }^{55}$ Ruth Park, Playing Beatie Bow, Puffin Books, London, 1980. 